\title{
EMPOWERING RESILIENCE WITHIN THE SCHOOL CONTEXT
}

\author{
Vanja Kiswarday, MSc \\ Univerza na Primorskem, Pedagoška fakulteta, \\ Koper (Slovenia) \\ e-mail: vanjariccarda.kiswarday@pef.upr.si
}

\begin{abstract}
A b s tract
The aim of this article is first to familiarize readers with key conceptual constructs related to the resilience theory, focusing in particular on educational resilience. Emerging from resilience theory and models that are already used to foster resilience and as a consequence improve the quality of mental health and learning efficiency in different parts of the world, we are going to explore the prevalence of resilience fostering elements through the existing curriculum and pedagogical approaches in Slovenian elementary and secondary schools. We need to emphasise that resilience as a theoretical concept is not yet well known in Slovenia and there are no specialized programmes to foster resilience in children and youth, but we believe that quality teaching, which is based on European and national educational policies, already includes great part of it. With our research we would like to find out which educational approaches, recognized as resilience fostering approaches in resilience theory, are considered to be most important and are most widespread among our teachers. We are looking to explore the characteristics of teachers in Slovenia who perceive themselves as competent, motivated and effective in the educational fields and approaches that are also significant and recognized in the process for developing resilience in children and youth. For this matter we are going to prepare a questionnaire that measures teachers' mindsets, and their standpoints about their own competences, effectiveness, and willingness for developing students' skills and competences that increase and enable resilience through the educational process. The research work is in the beginning stage; thus only the theoretical bases are presented in this paper.

Key words: resilience, inclusion, children on risk, curriculum, holistic learning and teaching, problem solving, mental health
\end{abstract}

\section{The concept of resilience}

Masten and Obradović (2006, p. 14) explain resilience as a broad conceptual umbrella, covering many concepts related to positive patterns of adaptation in the context of adversity. Within the notion of resilience two critical conditions are contained: exposure to significant threat or severe adversity and achievement of positive adaptation despite major assaults on the developmental process. 
For Lois Murphy (cited in Masten \& Obradović, 2006 p. 15) adaptive quality of living involves two dimensions: adapting to the environment and maintaining a person's internal integration. An individual, especially a child or a young person, daily participates in many different systems (family, school, religious, cultural, recreational, and social environments) that mutually interact with his/her development. In Bronfenbrenner's bio-socio-ecological model all this systems interdependently interact with each other. Thus risk and protective factors operate across settings and at different levels in differing environments (Masten, 2008, Clay, 2005). This gives a responsibility for development of resilience to the community, and encompasses also the school system as one of the most important systems for children and young people. Environmental and social contexts of a young person make it possible to work simultaneously on reducing risk factors and promoting protective factors.

The international resilience project (Grotberg, 1997) that included 30 countries defined resilience "as a universal capacity which allows a person, group or community to prevent, minimize or overcome the damaging effects of adversity. Resilience may transform or make stronger the lives of those who emerge in exceptional situations. The resilient behaviour may be in response to adversity in the form of maintenance or normal development despite the adversity, or a promoter of growth and social cohesion beyond the present level of functioning. Further, resilience may be promoted not necessarily because of adversity, but, indeed, may be developed in anticipation of inevitable adversities" (Grotberg, 1997).

Resilience is an interactive and accumulating process of developing different skills, abilities, knowledge and insight that a person needs for successful adaptation or to overcome adversities and meet challenges. For Grotberg (1999) it consists of inner personal strengths, social and interpersonal skills, and external supports and resources, all of them contributing to essential blocks (self-confidence, self-image, responsibility, independence, initiative, effectiveness, trust) that build personal resilience.

Inner personal strengths are determined by bio-psycho-social characteristics and conditions of the individual, when he/she is seeking to find an answer on "Who I am". They enable the development of personal strengths and build the child's' selfconfidence, self-image, responsibility, independence.

External supports and resources are connected to socio-cultural and environmental factors and are linked to direct and indirect interpersonal relations of individuals within the family and within the wider community (peer relationship, household rules, shared values, school, access to services, health and recreation resources, church, etc.). These "I have" features are conducive to a child's realisation about the reliability of love, belonging, structure and support within the family and community. They build a child's' trust.

Social and interpersonal skills represent one's skills and knowledge capital that prepare him/her for active participation, effective communication, understanding and expressing feelings, good problem solving, setting realistic and 
optimistic future goals. These "I can" features build a child's initiative and effectiveness.

Even if these features seem quite easy to acquire, the results of the International Resilience Project showed that resilience was promoted in only $38 \%$ of nearly 600 children from 30 different countries (Grotberg, 2005). Children need help and support from adults who know how to foster resilience to become resilient and to successfully cope with difficult life situations. They don't need to meet all the listed features, but most of them. Because of the powerful contribution that resilience offers to a child's development, dissemination of the paradigm that claims the shift from risk to resilience and competence is imperative and binding for the society (Wolin \& Wolin, 1997, Benard, 1998, Lewis, 2000, Masten, 2006).

Masten and Obradović (2006, pp. 14) list nine adaptive systems that have a crucial role in resilience, and also more broadly in human development:

- Learning systems of the human brain (problem solving, information processing)

- Attachment system (close relationships with care providers, friends, partners, spiritual figures)

- Mastery motivation system (self-efficacy processes, reward systems related to successful behaviour)

- Stress response systems (alarm and recovery systems)

- Self-regulation systems (emotion regulation, executive functioning, activation and inhibition of attention or behaviour)

- Family system (parenting, interpersonal dynamics, expectations, cohesion, rituals, norms)

- School system (teaching, values, standards, expectations)

- Peer system (friendships, peer groups, values, norms)

- Cultural and societal systems (religion, traditions, rituals, values, standards, laws).

When these systems are available and functional, then individual resilience is common. Intervention is requested when these systems are damaged or malfunctioning because this signifies overwhelming threats to children and their development.

\section{Models for fostering resilience}

During the last decade a number of different models were developed to foster resilience in children and youth. Corresponding to different needs that young people have regarding their individual life circumstances Cove et al. (2005 pp. 3-4) grouped these models into three major categories that can be autonomous or combinative. 
- Compensatory models with a direct and independent influence on the outcome, focus on neutralisation of negative consequences and chain reactions due to exposure to risk;

- Challenge models where stressors are treated as potential enhancers of successful adaptation which strengthen the child for future challenges; and

- Protective factor models focused on changing and modifying the child's reaction and response to the risk factors.

Researchers appeal for an accelerated development of prevention programmes that should target multiple risks that appear within almost every child's life. Society, especially schools, should pay more attention to adding resources in a child's life that may effectively counterbalance high risk and strengthen protective factors for development. The emphasis should be given to more personal relationships within school environments; partnership between school and family; detection of students' talents and strengths; reinforcement of learning strategies, motivation, self efficacy, basic knowledge skills, literacy and hopefulness that motivates human adaptation - because those who see changes as challenges tend to search for opportunities that changes can bring.

\section{Personal characteristics of resilient children}

The major implication from resilience research for practice is to enhance and support children's development when it is endangered by adversities and threats and also to strengthen children's skills and features in terms of prevention to help them grow into competent and resilient people who have a sense of personal identity and efficacy, who are able to make decisions, set goals, and believe in their future. The primary focus of any prevention, education, and youth development effort should focus on meeting children's and youths' basic human needs for caring, connectedness, respect, challenge, power.

Eight key qualities/predispositions were derived as the most characteristic personal attributes of the resilient child (Clarke and Clarke, 1984; Garmezy, 1985; Werner and Smith, 1988; Benard, 1993, all cited in Murray et al. 2003):

1) Having stable relationships with peers.

2) Possessing well developed problem-solving skills.

3) Considering realistic future plans.

4) Having a positive sense of being able to achieve and deal effectively with tasks.

5) Experiencing success in one or more areas of their life.

6) Being able to communicate effectively.

7) Possessing a strong attachment with at least one adult.

8) Acceptance of responsibility for themselves and their behaviour. 
It should be underlined again that these characteristics do not stay as autonomous or self-employed personal traits but are in close and interactive coherence with other protective factors and mechanisms.

But as the mindset of children and youth plays a major role in influencing their behaviour, it is important that parents, teachers, and other care providers understand the mindset resilient children and youth possess so that they can attempt to nurture it during all of their interactions.

\section{Fostering resilience in the school context}

Without any doubt the most powerful source for fostering and developing resilience in children and youth is the family. But right after families, the next major influence goes to the schools. Primary schools and their staff play a key role in children's development. Since the obligatory schooling is just an entering stage of life long learning and competent adulthood, the quality of time that our children spend in school (that covers at least one third of theirs active day) is very important. Trough student-centred and holistic education all included children and youth should get enough stimulations and opportunities to develop various competences, life skills and optimistic life orientation. For all children, but especially for those whose families cannot realize their role, school and teachers have the opportunity, chance and responsibility to interfere and competently cover wider educational goals and life skills. Werner and Smith (1989, cited in Benard, 1998) found that teachers were the most frequently encountered positive role models for children, outside their circle of family members. Furthermore, there are so many personal life stories that communicate the powerful role that schools and teachers have to tip the scales from risk to resilience.

Yet, from the other perspective, classroom or school can also be viewed as a system that may be threatened by adversities like exclusion, criticism, bullying and inappropriate learning methods. This steers the need for promoting resilience in the school context and establish resilient classrooms. Special attention should be dedicated to children with special needs, whose vulnerability can increase and cause new problems (comorbidity) when their needs are overlooked or neglected (Margalit, M., \& Idan, O., 2004). In such case resilience is hard to be developed (Masten \& Obradović, 2006).

\section{Teacher's role in fostering resilience}

Research findings (Masten et al., 2008) implicate schools in many of the processes that promote positive development and prevent problems in the general population. In addition, the school context affords opportunities to facilitate resilience among children at risk of poor outcomes due to exposure to adversities (e.g. parents' divorce, family violence, maltreatment, chronically illness, poverty, special learning needs). 
According to researchers and practitioners, the resilience framework may well contribute to learning efficacy. The premise of a resiliency programme is that when a protective environment is established and protective factors are increased, school climate and attendance will improve as well as students' academic achievement. Students will be less vulnerable to becoming involved in inappropriate behaviours. In the school context resilience may well promote a shift from an at-risk focused point of view to the child. This switches teachers from seeing children and their families through a deficit lens to a more holistic view that also includes strengths and capacities.

A teacher should never be only an instructor of academic skills, but also a confident and positive model for personal identification. As a person and as a professional $s$ (he) should convey caring support to students by listening to them, demonstrating kindness, respect, compassion throughout the educational process. By expressing high expectations teachers can structure and guide students' behaviour and challenge their learning motivation and efficiency. Finally, a teacher is the one who should provide numerous opportunities for students to participate and contribute within a class, school and local environment to express their opinions, ideas, creativity and knowledge, to make choices, solve problems, work together, help others, interact with each other and with the community.

Benard (1998) recognises teachers as promoters of three crucial environmental protective factors:

- Connection that is transmitted through authentic relationships that communicate respect, availability, interest, and compassion. Such rapport also builds the critical motivational foundation for successful learning.

- Competence that follows high expectations, guided learning strategies and understanding metacognition. Such an approach influences the learning structure, guides behaviour and challenges students with higher learning goals.

- Contribution that builds class and school community, personal value, involvement, responsibility, belonging by enhancing students' active and reflective learning, critical thinking, dialogue, collaborative work, curriculum planning, using participatory evaluating strategies, creating class rules, peer support, community service and connection.

\section{An example model for fostering resilience in the school context}

Henderson (2002) identified four basic strategies to build resilience and add the power of protective factors to people's lives. These strategies correspond to basic human needs across the life span and help people to integrate well in systems that embody them. She underlines the strengths approach in education that was promoted by Seligman, resilience researcher, who in 1998 established the Positive Psychology branch of the American Psychological Association.

1) Communicate The Resilience Attitude. We are fostering resilience via verbal and nonverbal communication. It is the personal attention to the child that 
matters, and the belief that problems can be solved or successfully overcome. The real challenge is the simultaneous approach - to identify strengths and their adaptive systems for each appearing problem.

2) Adopt a "Strengths Perspective." Teachers and school counsellors are in a position to notice when children are having difficulties and in collaboration with parents and other professionals suggest further help, when needed. Yet it is essential to give so much attention to strengths and skills development as we dedicate to the diagnostic of problems.

3) The resilience wheel embraces a child or youngster with external supportive systems and stimulates her/him for active participation of solving the recognised problem(s), based on activation of individual strengths. The more systems we include, the more structure, help and support a child gets.

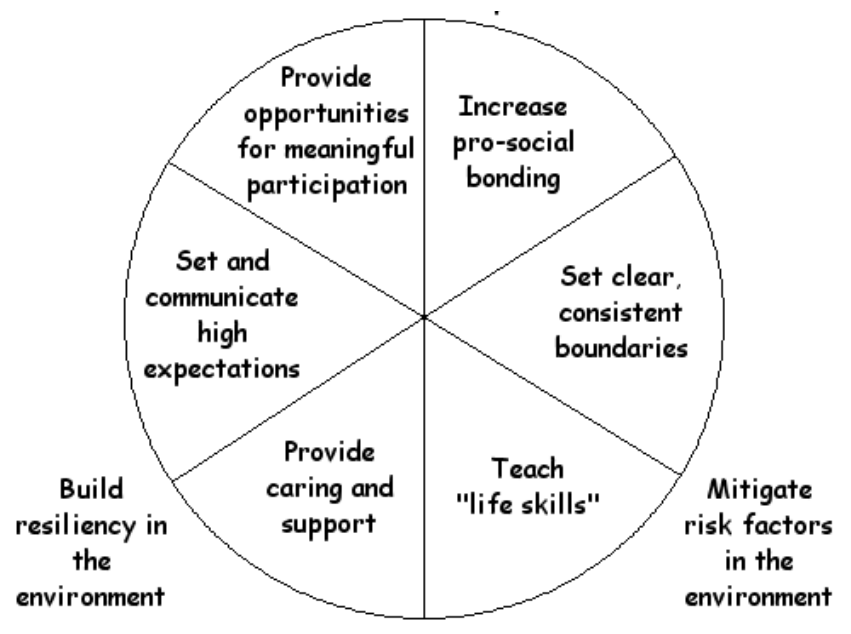

Picture 1 The resilience wheel (Handerson, 2007, p.10)

Step 1: Teachers should care about positive, respectful and caring relationships with students and among them. Through forming close and sustained relationships, teachers can support students to develop relationships and skills, confidence, help them learn to manage emotions and behaviours. They should also stimulate students to join different extracurricular activities that enhance students' talents and social skills.

Step 2: School rules give students structure. By setting and maintaining clear assignments and boundaries students get a frame where they know what is expected from them and what the consequences are. That gives them a sense of safety and experience of cohesive coexistence in the class.

Step 3: Teachers should be high valuing and stimulating learning approaches and methods that enhance developing life skills and strategies that are commonly needed every day. Life skills such as communication, collaboration, 
problem solving, conflict resolution, planning, learning motivation, basic academic skills, give a fundamental base and the strength needed for successful coping with new lifespan challenges and avoiding inappropriate behaviour.

Step 4: Providing care and support is one of most crucial things in the resilience wheel, because children and youth usually don't have enough knowledge, experience and strength to cope with problems on their own. A caring relationship with an important adult is one of the most important protective factors in building resilience in children and young people. Students who are positively engaged in a relationship with a teacher also improve their learning efficiency because they are more motivated to collaborate within a caring and safe school environment.

Step 5: Setting high, but realistic, expectations involves identifying and supporting individualised learning steps. It should not be directed towards demanding instant perfection but in stimulating creative thinking and learning. Low expectations and acceptation of failures demotivate students' learning engagement and stimulate them in searching inappropriate ways to get attention.

Step 6: Providing opportunities for "meaningful contribution" to schoolmates and others gives sense of value and necessity within the school, class (community). It gives the opportunity to use gathered knowledge and skills in various situations, to activate higher mental processes, to practice and develop life skills (intro and interspectional skills, self control, problem solving, planning, decision making, setting goals, collaborating with an authority and school mates, supporting the others, persisting, being flexible). We should never underestimate the value of volunteering - by helping the others a young person can get a new life perspective.

4) Give it time and never give up. Children usually test teachers' and other adults' patience and persistence. Thus it is important to act patiently and constructively by giving a chance of tasting success and stimulate for positive behaviour. Developing resilience is a life long process and resilient behaviour can vary in different developmental stages and in different adversity situations.

\section{Discussion}

It is good and encouraging that the above presented strategies are not unknown to teachers; they match the competences that professional European teachers should possess. Yet, we cannot be satisfied with our schools where we find unmotivated students, estranged from the learning process, with low learning efficiency and high psychosomatic problems incidence. Thus, we are interested to find what inhibits teachers to meet the aims; what are the obstacles and difficulties and where do they see potentials for overcoming them.

Mindful fostering of resilience is especially important during the transition to the inclusive school, when numerous demanding changes and unknown situations may appear, difficult and stressful for all - students with special needs, their schoolmates, teachers and parents. Thus, we need to change our mindsets, and shift 
our education paradigm from focusing on the difficulties and problems to resilience - through caring and collaborative relationships, strengths and competences development and encouraging opportunities for success. Resilience paradigm enables students and teachers to meet modern educational challenges, create a positive and collaborative school climate, achieve higher learning effectiveness and better social cohesion in class and school.

\section{Bibliography}

1) Benard, B. (1998). How to Be a Turnaround Teacher/Mentor. Reaching Today's Youth, Spring 1998. Pridobljeno 12.5.2009 s svetovnega spleta: http://www.resiliency.com/htm/ turnaround.htm

2) Clay, V., Silberberg, S. (2004). Resilience identificator resources. Family Action Centre, Faculty of Health. University of Newcastle._Pridobljeno 2.4.2009 s svetovnega spleta: unlforfamilies.unl.edu/satellite/doc/Resilience_identification_resources.doc

3) Cove, E., Eiseman, M. Popkin, S.J. (2005). Resilient Children: Literature Review and Evidence from the HOPE VI Panel Study. Final Report. December 2005. The Urban Institute Metropolitan Housing and Communities Policy Center street, NW, Washington, DC. Pridobljeno 12.6.2009 s svetovnega spleta: http://www.urban.org/UploadedPDF/411255_resilient_children.pdf

4) Grotberg, E. (1995). A Guide to Promoting Resilience in Children: Strengthening the Human Spirit. Pridobljeno 12.6.2009 s svetovnega spleta: http://resilnet.uiuc.edu/library/grotb 95b.html

5) Grotberg, H.E. (1997). The International Resilience Project: Findings from the Research and the Effectiveness of Interventions, Civitan International Research Center, UAB. Pridobljeno 7.4.2009 s svetovnega spleta: http://resilnet.uiuc.edu/library/grotb97a.html.

6) Grotberg H.E. (2005). Resilience for Tomorrow. International Council of Psychologists Convention, Iguazu,Brazil, July 18, 2005

7) Henderson, N. (2002). Fostering Resiliency in Children and Youth: Four Basic Steps for Families, Educators, and Other Caring Adults. http://ns1.integrastrategic.com/userfiles/files/ HendersonResiliencyAdolescents.pdf

8) Henderson, N. (2007). Resiliency in action. Hard-Wired to Bounce Back. Resiliency In Action, Inc.

9) Lewis, J. (2000). The Concept of Resilience as an overarching aim and organising principle for Special Education, and as a prerequisite for Inclusive Education. International Special Education Congress, 2000. Univ. of Manchester, UK.

10) Margalit, M., \& Idan, O. (2004). Resilience and hope theory: An expanded paradigm for learning disabilities research. Thalamus, 22 (1), 58-64

11) Masten, A.S., Obradović, J. (2006). Competence and resilience in development. Ann. N.Y. Acad. Sci. 1094: p. 13-27.

12) Masten, A.S., Herbers, J.E. Cutuli, J.J.Lafavor, T.L. (2008). Promoting competence and resilience in the school context. Professional school counseling, dec. 2008. Pridobljeno 9. 4. 2009 s svetovnega spleta: http://www.questia.com/app/direct/SM.qst.

13) Murray Nettles, S., Robinson, F.P. (1998). Exploring the dynamics of resilience in an elementary school. University of Maryland and Johns Hopkins University and Frances P. 
Robinson, Principal Stanton Elementary School, Washington, D.C. http://ceep.crc.uiuc.edu/ eecearchive/books/resguide/nettles.pdf

14) Wolin, S. \& Wolin, S., 1997. Shifting Paradigms: Easier Said Than Done. Resiliency in Action Magazine - Fall 1997. Pridobljeno 12. 5. 2009 s svetovnega spleta: http:// projectresilience.com/framespublications.htm

Metodički obzori 7(2012)1

Pregledni rad

UDK: 371.3:159.913](497.4)

Received: 13. 11. 2010.

\title{
RAZVIJANJE REZILIENTNOSTI (ŽIVOTNE OTPORNOSTI) U ŠKOLI
}

\author{
mag. Vanja Kiswarday \\ Univerza na Primorskem, Pedagoška fakulteta, Koper (Slovenija) \\ e-mail: vanjariccarda.kiswarday@pef.upr.si
}

\begin{abstract}
Sažetak
Namjena ovog članka je upoznati čitatelje sa ključnim konceptualnim pojmovima teorije reziliencije, koji su povezani sa poticajem razvoja reziliencije odnosno životne otpornosti u školskoj sredini. Proučavanjem teorije reziliencije i stranih obrazovnih modela, koji su svojom usmjerenošču u razvoj reziliencije $u$ okviru škole poboljšali razinu mentalnog zdravlja među učenicima, kao i njihov uspjeh, želimo utvrditi u kojoj mjeri nastavnici slovenskih osnovnih i srednjih škola u svom pedagoškom radu primjenjuju načela, metode, pristupe i vještine, koje prema teoriji reziliencije potiču razvoj životne otpornosti naših učenika. Iako teorijski koncept reziliencije u Sloveniji još nije identificiran i još uvijek nemamo razvijenih smjernica koje bi bile posebice usmjerene na razvoj reziliencije kod djece i adolescenata, smatramo da je ona svejedno u velikoj mjeri utkana u načela, smjernice i ciljeve suvremene europske i nacionalne percepcije odgoja i obrazovanja, i možemo je u velikoj mjeri realizirati već i sa kvalitetnom, prema učeniku usmjerenom nastavom. Sa istraživanjem i u tu svrhu pripremljenim upitnikom, želimo utvrditi kakve stavove i uvjerenja imaju nastavnici do pojedinih čimbenika koji potiču razvoj reziliencije. Također želimo utvrditi koje karakteristike nastavnika i škola na kojima predavaju, imaju najveći utjecaj na identifikaciju važnosti tih čimbenika. Istraživanje još nije završeno, zato su u ovom članku predstavljene samo teorijske osnove.
\end{abstract}

Ključni pojmovi: reziliencija, uključivanje, rizične skupine djece $i$ adolescenata, kurikulum, integrirana nastava, prevladavanje teškoća, mentalno zdravlje učenika 


\section{RAZVIJANJE REZILIENTNOSTI (ŽIVLJENJSKE ODPORNOSTI) V ŠOLI}

\section{Povzetek}

Namen prispevka je bralcem predstaviti ključne konceptualne pojme teorije rezilientnosti, ki so povezani s spodbujanjem razvoja rezilientnosti oz. življenjske odpornosti, $v$ šolskem polju. S proučevanjem teorije rezilientnosti in tujih vzgojno izobraževalnih modelov, ki so $\mathrm{z}$ usmerjenostjo $\mathrm{v}$ razvoj rezilientnosti v okviru šole izboljšali tako stopnjo duševnega zdravja med šolarji, kot tudi njihove učne učinkovitosti, želimo ugotoviti, v kolikšni meri učitelji slovenskih osnovnih in srednjih šol $\mathrm{v}$ svoje pedagoško delo vključujejo načela, metode, pristope in spretnosti, ki glede na teorijo rezilientnosti, spodbujajo razvoj življenjske odpornosti naših šolarjev. Čeprav teoretični koncept rezilientnosti v Sloveniji še ni prepoznan, in še nimamo razvitih smernic, ki bi bile posebej osredotočene na razvoj rezilientnosti pri otrocih in mladostnikih ugotavljamo, da so le-te v veliki meri vtkane $\mathrm{v}$ načela, smernice in cilje sodobnega evropskega in nacionalnega pojmovanja vzgoje in izobraževanja in jih potemtakem lahko v veliki meri uresničujemo že s kakovostnim, $v$ učenca usmerjenim izvajanjem pouka. $\mathrm{Z}$ raziskavo, in $\mathrm{v}$ ta namen pripravljenim vprašalnikom, želimo ugotoviti kakšna stališča in prepričanja imajo učitelji do posameznih dejavnikov, ki spodbujajo razvoj rezilientnosti. Ugotoviti želimo tudi katere karakteristike učiteljev, in šol na katerih poučujejo, najbolj vplivajo na prepoznavanje teh dejavnikov kot pomembnih. Raziskava še ni zaključena, zato bodo $\mathrm{v}$ tem prispevku predstavljena zgolj teoretična izhodišča.

Ključne besede: rezilientnost, inkluzija, rizične skupine otrok in mladostnikov, kurikul, celostno poučevanje, premagovanje težav, duševno zdravje šolarjev 